\title{
Assessment of hydrogeochemical status of groundwater in a coastal region of Southeast coast of India
}

\author{
S. Chidambaram ${ }^{1} \cdot$ J. Sarathidasan ${ }^{1} \cdot$ K. Srinivasamoorthy ${ }^{2} \cdot$ C. Thivya ${ }^{3} \cdot$ R. Thilagavathi ${ }^{1} \cdot$ M. V. Prasanna ${ }^{4}$. \\ C. Singaraja ${ }^{5} \cdot$ M. Nepolian ${ }^{1}$
}

Received: 22 June 2014 / Accepted: 27 December 2017 / Published online: 30 January 2018

(c) The Author(s) 2018. This article is an open access publication

\begin{abstract}
A study was conducted in a coastal region of Cuddalore district of Tamil Nadu, India, to identify the hydrogeochemical processes controlling the groundwater chemistry. The major geological units of the study area are sandstone, clay, alluvium, and laterite soils of Tertiary and Quaternary age. A total of 64 groundwater samples were measured for major ions and stable isotopes. Higher electrical conductivity values indicate the poor quality groundwater along the coastal region. Saline water intrusion mainly affects the hydrochemical composition of the aquifer water reflected by Na-Cl-type waters. $\mathrm{Cl}^{-} /$ $\left(\mathrm{Cl}^{-}+\mathrm{HCO}_{3}^{-}\right)$ratio also indicates the mixing of fresh groundwater with saline water. The results of $\delta \mathrm{D}$ and $\delta^{18} \mathrm{O}$ analyses show that isotopic compositions of groundwater ranges from -7.7 to $-2.1 \%$ for $\delta^{18} \mathrm{O}$ and from -55.6 to $-18.5 \%$ for $\delta \mathrm{D}$. Correlation and factor analysis were carried out to find the association of ions and to determine the major factors controlling the groundwater chemistry of the region. The study indicates that ion exchange, weathering, salt water intrusion along the coast, and anthropogenic impacts are the major controlling factors for the groundwater chemistry of the region.
\end{abstract}

Keywords Coastal aquifers $\cdot$ Salt water intrusion $\cdot$ Weathering $\cdot$ Isotopes $\cdot$ Cuddalore

\section{Introduction}

The quality of coastal aquifers is controlled by the variations of hydrogeochemical processes like salt water intrusion, geogenic process (weathering, ion exchange and rock-water interaction), and anthropogenic activities (agriculture, industry and urbanization). Table 1 explains the various controls of hydrogeochemical processes in the coastal aquifers worldwide. Every part of the country has its own causative factors for the variation of groundwater quality. So, it is important

M. V. Prasanna

geoprasanna@gmail.com

1 Department of Earth Sciences, Annamalai University, Annamalai Nagar 608002, India

2 Department of Earth Sciences, Pondicherry University, Pondicherry, India

3 Department of Geology, University of Madras, Guindy Campus, Chennai 600025, India

4 Department of Applied Geology, Faculty of Engineering and Science, Curtin University Malaysia, CDT 250, 98009 Miri, Sarawak, Malaysia

5 Presidency College, Chennai, India to determine the chemistry of groundwater quality for its sustainable development (Subba Rao et al. 2012). The area chosen for this study is in a such complex environment, occupied by the river Uppanar, Perumal lake, industries, and agricultural field.

Groundwater is the only dependable water resource for human consumption, as well as for drinking, irrigation, domestic, and industrial uses for many people around the world. Rapid depletion of groundwater supplies due to continuous populace growing and industrial development threatens the quality of water in many aquifers. Many researchers have stated that rapid urbanization along the coastline aquifers openly or secondarily affects the groundwater quality and quantity (Boukari et al. 1996; Lambrakis 1998; Zilberbrand et al. 2001; Foppen 2002; Faye et al. 2004). The process of assessing the suitability of groundwater for various purposes requires a proper thought on the hydrochemistry of an area. Further, it is important to understand how water-rock interaction (weathering) or any type of anthropogenic impact affects groundwater quality (Todd 1980; Kelley 1940). Much of the groundwater in coastline aquifers in India is affected from seawater intrusion due to over-extraction. However, hydrogeochemical patterns are 
Table 1 List of studies carried out worldwide on coastal aquifers

\begin{tabular}{|c|c|c|c|c|}
\hline S. no. & Researchers & Year & Study areas & Controls of hydrogeochemical processes \\
\hline 1. & Laluraj et al. & 2005 & Coastal zones of Cochin, India & Influence of saline water incursion \\
\hline 2. & Ahmad et al. & 2008 & Coastal region of Oman & Saltwater intrusion and agricultural activities \\
\hline 3. & Carol et al. & 2009 & Samborombon Bay, Argentina & Salinization processes \\
\hline 4. & Silva-Filho et al. & 2009 & Rio de Janeiro coastal aquifer, SE-Brazil & $\begin{array}{l}\text { Domestic wastewater and not by marine water } \\
\text { encroachment }\end{array}$ \\
\hline 5. & Olufemi et al. & 2010 & Lagos Metropolis, Nigeria & Impact of saline intrusion \\
\hline 6. & Giménez-Forcada & 2010 & Coastal plains of Elba Island (Tuscany, Italy) & Seawater intrusion \\
\hline 7. & Karmegam et al. & 2010 & $\begin{array}{l}\text { Coastal Aquifer in and around Kalpakkam, South } \\
\text { India }\end{array}$ & $\begin{array}{l}\text { Ion exchange processes, recharge processes and saline } \\
\text { water intrusion }\end{array}$ \\
\hline 8. & Chidambaram et al. & 2010 & Portnova to Pumpuhar, southeast coast of India & Seawater intrusion \\
\hline 9. & Mohapatra et al. & 2011 & Puri city in Orissa State, India & $\begin{array}{l}\text { Organic matter degradation/ } \mathrm{Fe}(\mathrm{III}) \text { reduction and } \\
\text { anthropogenic pollution, seawater intrusion }\end{array}$ \\
\hline 10. & $\begin{array}{l}\text { Bhuvana } \\
\text { Jagadeeswari and } \\
\text { Ramesh }\end{array}$ & 2012 & Chennai, India & Seawater intrusion \\
\hline 11. & Thilagavathi et al. & 2012 & Coastal aquifers of Pondicherry regions & $\begin{array}{l}\text { Rock weathering processes, agricultural influences } \\
\text { and seawater intrusion }\end{array}$ \\
\hline 12. & Wang and Jiao & 2012 & Pearl River Delta, China & Ion exchange processes and mixing of seawater \\
\hline 13. & Mongelli et al. & 2013 & North-western Sardinia, Italy & Seawater intrusion and water-rock interaction \\
\hline 14. & Anis et al. & 2013 & coastal flood plain: Cap Bon, Tunisia & Seawater intrusion \\
\hline 15. & Fengshan et al. & 2014 & Coastal Region of Tangshan, China & Rock water interaction and saline water intrusion \\
\hline 16. & Singaraja et al. & 2015 & $\begin{array}{l}\text { Coastal region of Thoothukudi district, Tamil Nadu, } \\
\text { India }\end{array}$ & Seawater intrusion \\
\hline 17. & Barut & 2015 & $\begin{array}{l}\text { Coastal karst aquifer, Mandalia Bay (southeastern } \\
\text { Aegean Sea coasts) }\end{array}$ & Saline water intrusion \\
\hline 18. & Surinaidu & 2016 & Central Godavari delta, India & $\begin{array}{l}\text { Seawater intrusion, dissolution of evaporites in the } \\
\text { groundwater and ion exchange process }\end{array}$ \\
\hline 19. & Papazotos et al. & 2016 & Marathon coastal plain, Greece & $\begin{array}{l}\text { Seawater intrusion, reverse ion exchange and nitrate } \\
\text { concentration }\end{array}$ \\
\hline 20. & Singh et al. & 2017 & Tuticorin town, Southeast coast of India & $\begin{array}{l}\text { Seawater intrusion due to high rate of withdrawal of } \\
\text { groundwater }\end{array}$ \\
\hline 21. & Subba Rao et al. & 2017 & Coastal region of Andhra Pradesh, India & $\begin{array}{l}\text { Rock-water interaction, sluggish drainage conditions } \\
\text { due to influences of geogenic, anthropogenic and } \\
\text { marine sources }\end{array}$ \\
\hline
\end{tabular}

complex because of the input from different water sources (Subba Rao 2006; Sanford and Pope 2010). Generally saline water intrusion in coastal regions occurs naturally, but it can be aggravated due to the exploitation of coastal aquifers as water sources (Martinez and Bocanegra 2002; Ozler 2003). In addition to the natural salinity of groundwater, anthropogenic activities contribute significantly to the deterioration of water quality (Egun 2010). Thus, the main objective of the study was to identify the factor controls the groundwater chemistry in the coastal region.

\section{Study area}

The study area is situated in a coastal region of Cuddalore district, Tamil Nadu, India, which lies between north latitudes $11^{\circ} 44^{\prime} 34^{\prime \prime}$ and $11^{\circ} 29^{\prime} 59^{\prime \prime}$ and east longitudes $79^{\circ} 35^{\prime} 06^{\prime \prime}$ and $78^{\circ} 46^{\prime} 11^{\prime \prime}$ (Fig. 1). The region is chiefly composed of Tertiary and Quaternary formations. Tertiary formation includes sandstone, clay, and grit sand, whereas Quaternary formation mostly covered by fluvial sediments of silt, clay, fine- to coarse-grained sand, and laterite. Tertiary formation gently dips towards east-southwest direction and it occurs at the depth of 100-457 m, and Quaternary formation occurs at the depth less than $30 \mathrm{mbgl}$ (Arogyasami 1967; Sundaram 1979). In some locations, sandstones intervene with clay lenses that underlie the alluvial sand up to a depth of $50 \mathrm{~m} \mathrm{bgl}$. Soils in these regions are of oxysol type with the thickness greater than $3 \mathrm{~m}$ (Subramaniam 1969).

The average annual rainfall in these regions for the period 2003-2012 was about $138.70 \mathrm{~mm}$. Uppanar is the major river in this region and it has developed a thick cover of alluvium with mixtures of sand, silt, and clay with the thickness varying from 10 to $15 \mathrm{~m}$ (Jeevanandam et al. 2006). It originates from the southern part of 




Fig. 1 Sampling location map of the study area

perumal Eri. It generally flows from south to north side and discharges into the Bay of Bengal. Subdentritic type of drainage pattern is noted in this region. The major occupation in the area is agriculture, with more than $60 \%$ of the population engaged in this activity. The study region lies in the coastline of less surface water resources. The level of groundwater development in this region is $89 \%$, which is noted in the semi-critical stage (CGWB 2009), resulting in anthropogenic contamination by seawater intrusion. All the industries of SIPCOT (Small Industries Promotion Corporation of Tamil Nadu) are situated near the NE part of coastal region in the study area. The industries surrounding this region have continuously discharging chemicals like sulfur, lime, pesticides and it leads to the subsurface pollution in the northeastern side of the region (Sankaran et al. 2009).

The Cuddalore sandstone and unconsolidated Quaternary alluvium form the potential and principal aquifer systems in this region and it covers up to a depth of about $100 \mathrm{~m} \mathrm{bgl}$ (CGWB 1997). Comparison of geoelectrical logging data (CGWB 1997) with depth-wise resistivity values at certain sites in the study area indicate discontinuous, unconfined and confined to semi confined aquifers constitute the major aquifer system in the study area.

\section{Methodology}

A total of 64 groundwater samples were collected from the study area during March 2011. The sample bottles are then labeled, sealed, and brought to the laboratory and conserved by adopting standard procedures by APHA (2005). $\mathrm{Ca}, \mathrm{Mg}, \mathrm{Cl}$, and $\mathrm{HCO}_{3}$ were measured by titration and $\mathrm{SO}_{4}, \mathrm{NO}_{3}, \mathrm{PO}_{4}$, and $\mathrm{H}_{4} \mathrm{SiO}_{4}$ were obtained by using Digital Spectrophotometer (ModelGS5 700A). Na and K were measured by flame photometer (Systronics mk-1/mk-III). The accuracy of chemical analysis was checked by computing the cation-anion balance and it is noted to be less than \pm 5 to $10 \%$ (Domenico and Schwartz 1990). Oxygen $\left(\delta^{18} \mathrm{O}\right)$ and deuterium $(\delta \mathrm{D})$ isotopes in the groundwater samples were measured with Isotopic Ratio Mass Spectrophotometer (FinniganDelta ${ }^{\text {plus }} \mathrm{Xp}$, Thermo Electron Corporation, Bermen, Germany). The standard deviation of the measurements is $\pm 1.72 \%$ o for oxygen and $\pm 0.8 \%$ o for hydrogen. The measurements of samples are periodically checked and calibrated with international isotope water standards recommended by IAEA (V-SMOW, GSIP and SLAP). The results are reported in terms of $\delta$ units (Permil 
deviation of the isotope ratio from the international standard $\mathrm{V}$-Smow), with $\delta$ being defined by

$\delta=\left[\left(R_{\text {sample }}-R_{\text {SMOW }}\right) /\left(R_{\text {SMOW }}\right)\right] \times 10^{3}$,

where $R=D / H$ or ${ }^{18} \mathrm{O} /{ }^{16} \mathrm{O}$.

\section{General parameters}

$\mathrm{pH}$ varies from 5.2 to 9.8 with an average 7.1, indicating slightly acidic to alkaline nature. EC values ranged from $928 \mu \mathrm{s} / \mathrm{cm}$ to $13,975 \mu \mathrm{s} / \mathrm{cm}$ with an average of $4850 \mu \mathrm{s} / \mathrm{cm}$ (Table 2). The spatial distribution of electrical conductivity (EC) values for groundwater samples is shown in Fig. 2. Higher EC values ( $>5250$ and $4250-5250 \mu \mathrm{s} / \mathrm{cm}$ ) occur in the north eastern and south-western region of the study area which lies along the coastline, with an aerial extent of about $116 \mathrm{sq} \mathrm{km}$. EC values range from 3000 to $4250 \mu \mathrm{s} / \mathrm{cm}$ in the central part of the region along the Uppanar river mouth, covering an area of about $104 \mathrm{sq} \mathrm{km}$. EC values from 2250 to $3000 \mu \mathrm{s} / \mathrm{cm}$ cover an area of about $95 \mathrm{sq} \mathrm{km}$ in the north western and south-eastern part of the study area followed by the ranges from 1750 to $2250 \mu \mathrm{s} / \mathrm{cm}$, covering a region of about $63 \mathrm{sq} \mathrm{km}$ in north western part. EC values $(<1750 \mu \mathrm{s} /$ $\mathrm{cm}$ ) cover an area of about $34 \mathrm{sq} \mathrm{km}$ in western part of the study area. Overall higher values were noted in the eastern part of the study area indicating the leaching of secondary salts and anthropogenic impact by agricultural activities and aquaculture apart from sea water intrusion. This may also be due to anthropogenic impacts from an industrial estate SIPCOT (Small Industries Promotion Corporation of Tamil $\mathrm{Nadu}$ ), which is located close to the study area. The longterm extraction of this coastal aquifer leads to the impact of the effluents generated by them.

\section{Geochemical processes}

\section{Piper plot}

Groundwater chemical data were processed on a Piper diagram (Piper 1944) to govern the compositional trends in groundwater, and this is shown in Fig. 3. This diagram indicates that samples plot in a range of hydrochemical facies, but the dominant facies observed are of $\mathrm{Ca}-\mathrm{Mg}-\mathrm{SO}_{4}-\mathrm{Cl}$, $\mathrm{Ca}-\mathrm{HCO}_{3}$, and $\mathrm{Na}-\mathrm{Cl}$ types. Groundwater in the study area indicates a pattern of hydrogeochemical trends, which starts from a $\mathrm{Ca}-\mathrm{Mg}-\mathrm{SO}_{4}-\mathrm{Cl}$ type via $\mathrm{Na}-\mathrm{HCO}_{3}$ type to $\mathrm{Na}-\mathrm{Cl}$ type; or from $\mathrm{Ca}-\mathrm{HCO}_{3}{ }^{-}$type directly to $\mathrm{Na}-\mathrm{Cl}$ type (Fig. 5). The path of mixing/migration of the groundwater composition (evolutionary path) with the seawater/end solutions can be obtained (Varma et al. 1996) from the Piper plot.
The effect of mixing of groundwater and its behavior on the Piper plot is well explained by Karmegam et al. (2011) and Singaraja et al. (2012). The observed pattern of compositional change suggests that cation exchange reactions are taking place when saltwater intrusion occurs (Jeen et al. 2001; Richter and Kreitler 1993). Most of the groundwater samples indicated a chemical composition dominated by sodium and chloride ions, which usually specifies a strong seawater influence (Pulido-Leboeuf 2004). The $\mathrm{Ca}-\mathrm{HCO}_{3}$ type of water probably signifies the partly flushed water or confined saline water source, in which $\mathrm{HCO}_{3}$ is higher than the alkaline earth cations $(\mathrm{Ca}+\mathrm{Mg})$ in equal concentrations (Mercado 1985). This is more prominent in Alluvial aquifer due to frequent flushing or recharge of groundwater. These excess $\mathrm{HCO}_{3}$ ions release the alkali ions (usually $\mathrm{Na}^{+}$) which enter into the groundwater by ion exchange processes (Jeen et al. 2001), whereas it results in the domination of $\mathrm{Na}^{+}$in groundwater.

\section{Chadda's hydrogeochemical process evaluation}

Generally, anionic composition of groundwater changes systematically from bicarbonate dominance to chloride dominance as groundwater flows from a recharge zone to a discharge area (Appelo and Postma 1996). The factors that influence the change of chemical composition of groundwater can be investigated graphically by plotting the difference in milli equivalent concentrations between alkaline earths (calcium + magnesium) and alkali metal elements (sodium + potassium) on the $x$-axis and the difference in milli-equivalent concentrations between weak acids (bicarbonate) and strong acids (chloride + sulfate) on the $y$ axis (Fig. 4). Samples falling in Field $2(\mathrm{Ca}-\mathrm{Mg}-\mathrm{Cl})$ are prominent between western side of the region and the coastal region possibly represents ion exchange reactions or an hydrochemical evolutionary path from $\mathrm{Ca}-\mathrm{Mg}-\mathrm{Cl}$ type water to $\mathrm{Na}-\mathrm{Cl}$ mixed sea water, whereas $\mathrm{Ca}-\mathrm{Mg}-\mathrm{Cl}$ represents the reveres ion exchange processes. Samples represent $\mathrm{Na}-\mathrm{Cl}$ type in Field 3 indicates the sea water mixing, which are mostly constrained in the coastal region and recharge characteristics was noted in Field 1.

\section{Relationship of $\mathrm{Cl}^{-} / \mathrm{HCO}_{3}{ }^{-}$ratio}

The $\mathrm{Cl}^{-} / \mathrm{HCO}_{3}{ }^{-}$ionic ratios were also studied to characterize the origin of salinity in groundwater. Ionic ratios of groundwaters are often used to assess the seawater intrusion in coastal regions (Sanchez-Martos et al. 1999; Kim et al. 2003). As previously noted in this study, TDS is an often a good surrogate for $\mathrm{Cl}^{-}$and thus the ratio is the good indicator of salinization due to the seawater encroachment (Nwankwoala and Judom 2011). The ratios of $\mathrm{Cl} / \mathrm{HCO}_{3}$ in the study area range between 0.28 and 13.47 and had 
Table 2 Chemical concentrations of groundwater samples collected in the study area (all values in $\mathrm{mg} / \mathrm{L}$ and except EC in $\mu \mathrm{S} / \mathrm{cm}$ and $\mathrm{pH}$ )

\begin{tabular}{|c|c|c|c|c|c|c|c|c|c|c|c|c|c|}
\hline S. no & $\mathrm{pH}$ & $\mathrm{EC}$ & TDS & $\mathrm{Ca}$ & $\mathrm{Mg}$ & $\mathrm{Na}$ & $\mathrm{K}$ & $\mathrm{Cl}$ & $\mathrm{HCO}_{3}$ & $\mathrm{SO}_{4}$ & $\mathrm{H}_{4} \mathrm{SiO}_{4}$ & $\mathrm{NO}_{3}$ & $\mathrm{PO}_{4}$ \\
\hline 1 & 7.1 & 6490 & 4111 & 130.00 & 75.00 & 57.00 & 6.00 & 468.00 & 230.00 & 15.00 & 29.50 & 1.30 & 0.01 \\
\hline 2 & 7.9 & 2365 & 1452 & 124.00 & 14.80 & 10.00 & 4.00 & 220.00 & 110.00 & 27.50 & 40.00 & 1.67 & 0.01 \\
\hline 3 & 7 & 3085 & 2014 & 98.00 & 17.10 & 116.00 & 28.00 & 250.00 & 112.00 & 68.40 & 69.50 & 1.98 & 1.70 \\
\hline 4 & 7.7 & 3465 & 2198 & 44.00 & 14.40 & 136.00 & 19.00 & 125.00 & 210.00 & 62.50 & 84.00 & 1.80 & 1.00 \\
\hline 5 & 7.8 & 928 & 587 & 40.00 & 18.00 & 21.00 & 3.00 & 97.00 & 67.09 & 36.00 & 112.50 & 1.84 & 0.69 \\
\hline 6 & 7.6 & 1365 & 857 & 42.00 & 19.50 & 36.00 & 5.00 & 135.00 & 65.00 & 34.50 & 104.00 & 1.69 & 0.23 \\
\hline 7 & 6.8 & 7020 & 4452 & 85.00 & 40.00 & 147.00 & 78.00 & 474.00 & 42.70 & 58.00 & 164.00 & 2.40 & 1.17 \\
\hline 8 & 6.6 & 4460 & 2798 & 75.00 & 35.00 & 125.00 & 105.00 & 420.00 & 35.00 & 46.00 & 168.00 & 22.15 & 2.20 \\
\hline 9 & 9.8 & 4210 & 2598 & 85.00 & 80.80 & 85.00 & 49.00 & 384.00 & 165.00 & 38.40 & 72.00 & 19.18 & 0.01 \\
\hline 10 & 6.4 & 4910 & 3125 & 66.00 & 26.00 & 31.00 & 2.00 & 415.00 & 36.60 & 22.70 & 112.50 & 7.90 & 0.01 \\
\hline 11 & 7.7 & 10,315 & 6687 & 120.00 & 62.00 & 60.00 & 10.00 & 365.00 & 125.00 & 2.50 & 39.00 & 6.30 & 0.01 \\
\hline 12 & 6.8 & 5130 & 3157 & 135.99 & 20.30 & 40.00 & 5.00 & 421.00 & 103.70 & 41.50 & 74.00 & 34.80 & 0.00 \\
\hline 13 & 6 & 6070 & 3745 & 220.00 & 85.00 & 178.00 & 15.00 & 480.00 & 310.00 & 24.00 & 164.00 & 19.60 & 0.52 \\
\hline 14 & 7.2 & 5580 & 3498 & 185.00 & 65.00 & 46.00 & 4.00 & 450.00 & 210.00 & 35.00 & 102.00 & 24.10 & 0.19 \\
\hline 15 & 7.1 & 6700 & 4278 & 112.00 & 80.00 & 62.00 & 5.00 & 327.00 & 156.00 & 30.50 & 42.00 & 8.26 & 1.19 \\
\hline 16 & 6.7 & 2600 & 1598 & 150.00 & 121.20 & 92.00 & 4.00 & 358.00 & 254.00 & 43.00 & 82.00 & 18.70 & 1.38 \\
\hline 17 & 5.7 & 2215 & 1386 & 128.00 & 69.00 & 29.00 & 2.00 & 320.00 & 156.00 & 42.60 & 192.00 & 1.67 & 0.01 \\
\hline 18 & 6.9 & 13,975 & 8949 & 86.00 & 25.60 & 85.00 & 6.00 & 575.00 & 439.20 & 19.50 & 191.00 & 34.40 & 0.01 \\
\hline 19 & 5.3 & 1655 & 1047 & 30.00 & 12.00 & 45.00 & 1.00 & 79.00 & 101.00 & 33.50 & 192.00 & 18.60 & 0.23 \\
\hline 20 & 5.7 & 1895 & 1250 & 57.99 & 31.00 & 10.00 & 2.00 & 110.00 & 97.60 & 48.30 & 134.00 & 13.00 & 0.01 \\
\hline 21 & 5.3 & 1515 & 898 & 39.00 & 18.00 & 7.00 & 1.00 & 70.89 & 48.80 & 35.50 & 62.00 & 18.00 & 0.01 \\
\hline 22 & 6.6 & 4885 & 3124 & 52.00 & 26.00 & 160.00 & 56.00 & 286.00 & 146.00 & 16.80 & 232.00 & 12.80 & 0.01 \\
\hline 23 & 5.7 & 3100 & 1945 & 37.00 & 16.00 & 106.00 & 8.00 & 124.00 & 207.40 & 28.50 & 222.00 & 9.80 & 0.01 \\
\hline 24 & 7.3 & 4360 & 2750 & 56.00 & 18.00 & 86.00 & 9.00 & 399.00 & 75.00 & 15.50 & 120.00 & 13.50 & 0.01 \\
\hline 25 & 7.2 & 4185 & 2600 & 50.00 & 16.00 & 120.00 & 3.00 & 410.00 & 140.30 & 24.50 & 144.00 & 62.20 & 0.01 \\
\hline 26 & 5.6 & 4960 & 3118 & 62.00 & 27.50 & 96.00 & 17.00 & 289.00 & 75.00 & 24.00 & 211.00 & 46.00 & 0.01 \\
\hline 27 & 6.3 & 2370 & 1524 & 50.00 & 16.00 & 64.00 & 12.00 & 203.83 & 36.60 & 18.10 & 170.00 & 19.40 & 0.01 \\
\hline 28 & 6 & 6545 & 4145 & 32.00 & 13.00 & 40.00 & 3.00 & 124.07 & 42.70 & 38.40 & 98.50 & 7.90 & 0.01 \\
\hline 29 & 5.3 & 1610 & 998 & 57.00 & 23.00 & 87.00 & 3.00 & 177.20 & 178.00 & 53.00 & 231.00 & 27.70 & 0.01 \\
\hline 30 & 5.2 & 11,530 & 7289 & 102.00 & 52.00 & 60.00 & 5.00 & 561.00 & 138.20 & 26.00 & 134.00 & 2.80 & 0.01 \\
\hline 31 & 7 & 3105 & 1954 & 97.00 & 48.00 & 119.00 & 15.00 & 385.00 & 143.80 & 45.00 & 99.00 & 7.10 & 0.14 \\
\hline 32 & 6.5 & 7090 & 4521 & 38.00 & 20.00 & 86.00 & 3.00 & 168.38 & 67.10 & 29.50 & 42.00 & 18.70 & 0.41 \\
\hline 33 & 6.6 & 4295 & 2722 & 55.00 & 16.00 & 84.00 & 56.00 & 194.97 & 103.70 & 31.70 & 113.00 & 37.80 & 0.76 \\
\hline 34 & 7 & 4925 & 3150 & 112.00 & 12.00 & 35.00 & 5.00 & 150.66 & 134.20 & 43.00 & 111.00 & 9.88 & 0.01 \\
\hline 35 & 6.6 & 4510 & 2789 & 33.00 & 14.00 & 106.20 & 42.00 & 168.39 & 73.20 & 45.30 & 86.00 & 10.80 & 2.30 \\
\hline 36 & 7.2 & 1850 & 1120 & 24.00 & 10.00 & 94.00 & 6.00 & 124.07 & 152.50 & 11.00 & 132.00 & 7.70 & 0.53 \\
\hline 37 & 6.9 & 1490 & 899 & 32.00 & 11.00 & 31.00 & 91.00 & 112.00 & 88.20 & 38.10 & 71.00 & 15.10 & 0.01 \\
\hline 38 & 6.8 & 1625 & 999 & 86.00 & 22.00 & 75.00 & 12.00 & 145.00 & 186.00 & 28.40 & 73.00 & 60.60 & 0.01 \\
\hline 39 & 7.8 & 5240 & 3245 & 20.00 & 16.00 & 83.00 & 4.00 & 97.00 & 160.00 & 32.50 & 20.00 & 27.80 & 0.01 \\
\hline 40 & 9.1 & 2315 & 1400 & 50.00 & 18.00 & 65.00 & 8.00 & 79.76 & 158.60 & 44.00 & 41.00 & 67.40 & 0.01 \\
\hline 41 & 9.2 & 4150 & 2598 & 26.00 & 8.00 & 94.50 & 19.00 & 81.00 & 153.00 & 22.00 & 162.00 & 48.00 & 0.01 \\
\hline 42 & 8.2 & 2405 & 1485 & 34.00 & 18.00 & 57.00 & 7.00 & 124.07 & 48.80 & 36.00 & 32.00 & 34.80 & 0.01 \\
\hline 43 & 9.3 & 1745 & 1108 & 53.00 & 20.00 & 44.00 & 5.00 & 150.60 & 115.70 & 15.20 & 44.00 & 86.40 & 0.01 \\
\hline 44 & 8.2 & 8250 & 5200 & 46.00 & 18.00 & 45.00 & 18.00 & 97.48 & 207.40 & 21.50 & 29.50 & 40.80 & 0.41 \\
\hline 45 & 9.1 & 1730 & 1000 & 76.00 & 37.00 & 38.00 & 9.00 & 79.76 & 179.00 & 40.50 & 28.00 & 78.20 & 0.01 \\
\hline 46 & 8.8 & 2320 & 1504 & 50.00 & 12.00 & 87.00 & 10.00 & 115.21 & 140.30 & 30.50 & 108.00 & 77.50 & 0.26 \\
\hline 47 & 9.5 & 1500 & 1005 & 74.00 & 53.00 & 61.00 & 25.00 & 97.49 & 350.00 & 34.50 & 114.00 & 50.60 & 0.01 \\
\hline 48 & 8.7 & 4475 & 2756 & 36.00 & 12.00 & 128.00 & 40.00 & 210.00 & 56.40 & 53.60 & 24.00 & 7.86 & 2.10 \\
\hline 49 & 8.7 & 13240 & 8542 & 35.00 & 17.00 & 40.00 & 25.00 & 97.49 & 69.40 & 33.50 & 39.00 & 28.40 & 0.19 \\
\hline 50 & 8.8 & 8615 & 5487 & 38.00 & 25.00 & 145.00 & 9.00 & 499.00 & 178.00 & 56.50 & 76.00 & 4.76 & 0.44 \\
\hline
\end{tabular}


Table 2 (continued)

\begin{tabular}{lrrrrrrrrrrrrr}
\hline S. no & pH & \multicolumn{1}{c}{ EC } & \multicolumn{1}{c}{$\mathrm{TDS}$} & $\mathrm{Ca}$ & $\mathrm{Mg}$ & \multicolumn{1}{c}{$\mathrm{Na}$} & $\mathrm{K}$ & $\mathrm{Cl}$ & $\mathrm{HCO}_{3}$ & $\mathrm{SO}_{4}$ & $\mathrm{H}_{4} \mathrm{SiO}_{4}$ & $\mathrm{NO}_{3}$ & $\mathrm{PO}_{4}$ \\
\hline 51 & 8.9 & 3005 & 1954 & 44.00 & 35.00 & 283.00 & 6.00 & 564.00 & 85.40 & 26.00 & 42.00 & 5.86 & 0.08 \\
52 & 7.5 & 4330 & 2689 & 37.00 & 18.00 & 46.00 & 9.00 & 150.66 & 36.60 & 48.50 & 32.00 & 6.54 & 0.13 \\
53 & 5.9 & 12,245 & 7798 & 68.00 & 18.00 & 66.00 & 9.00 & 125.00 & 87.80 & 56.00 & 99.00 & 37.00 & 0.01 \\
54 & 8.1 & 2110 & 1400 & 38.00 & 17.50 & 66.00 & 13.00 & 82.00 & 123.00 & 25.00 & 46.00 & 41.00 & 1.00 \\
55 & 6.1 & 6925 & 4402 & 47.00 & 18.00 & 97.00 & 3.00 & 159.52 & 134.20 & 69.00 & 103.00 & 19.70 & 0.01 \\
56 & 5.7 & 4680 & 2890 & 48.00 & 18.00 & 115.00 & 38.00 & 186.50 & 95.70 & 39.00 & 101.00 & 31.80 & 0.01 \\
57 & 6.5 & 9055 & 5654 & 41.00 & 20.00 & 129.00 & 5.00 & 221.55 & 152.50 & 49.50 & 141.00 & 8.74 & 0.01 \\
58 & 6.7 & 6940 & 4452 & 48.00 & 22.00 & 54.00 & 3.00 & 212.70 & 42.70 & 10.50 & 40.00 & 4.84 & 0.01 \\
59 & 7.2 & 8370 & 5400 & 30.00 & 15.00 & 216.00 & 5.00 & 407.67 & 146.40 & 15.50 & 30.00 & 3.74 & 0.01 \\
60 & 5.9 & 2215 & 1452 & 28.00 & 13.00 & 245.00 & 8.00 & 274.74 & 439.20 & 4.56 & 70.00 & 2.84 & 0.01 \\
61 & 7.7 & 3555 & 2230 & 29.00 & 16.00 & 141.00 & 12.00 & 168.39 & 158.60 & 28.00 & 44.50 & 28.50 & 0.40 \\
62 & 7.5 & 5780 & 3542 & 37.00 & 19.00 & 40.00 & 3.00 & 141.80 & 97.60 & 15.70 & 103.20 & 10.80 & 2.00 \\
63 & 7.8 & 2715 & 1804 & 49.00 & 23.00 & 174.00 & 5.00 & 325.00 & 48.80 & 6.50 & 71.00 & 7.74 & 0.01 \\
64 & 7.5 & 8825 & 5674 & 68.00 & 27.00 & 136.00 & 3.00 & 524.00 & 132.52 & 15.80 & 430.00 & 23.00 & 0.01 \\
\hline
\end{tabular}

Fig. 2 Spatial distribution of electrical conductivity (EC) in the study area

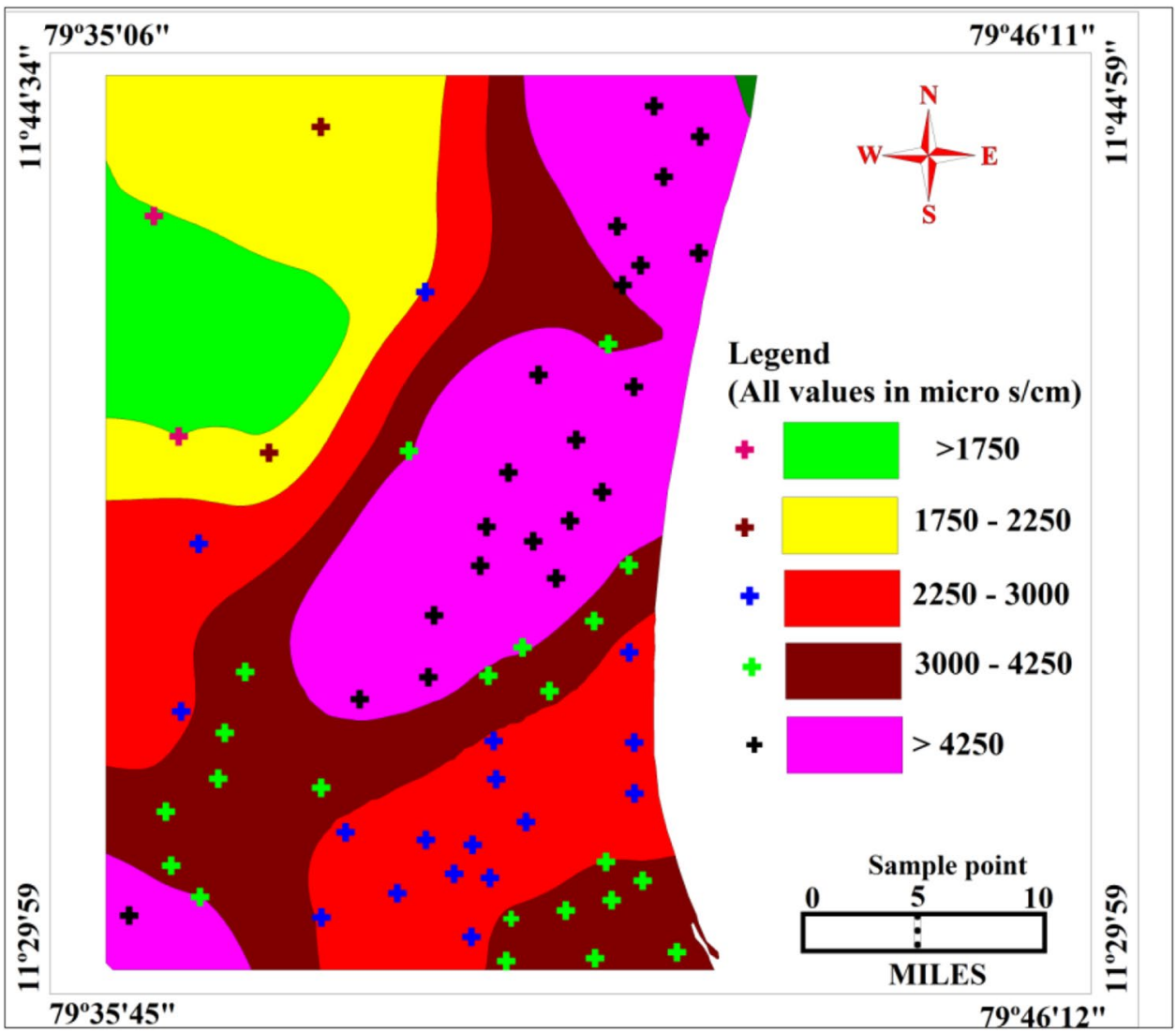

a strong positive direct relation with $\mathrm{Cl}^{-}$concentrations (Fig. 5). It shows the mixing of fresh groundwater with saline water. Based on $\mathrm{Cl} / \mathrm{HCO}_{3}$ ratios groundwater can be classified into unaffected $(<0.5)$, slightly or moderately affected (0.6-6.6), and strongly affected ( $>6.6$ ) by salinization process. (Revelle 1941; Todd 1959). On the basis of the ratio of $\mathrm{Cl}^{-} / \mathrm{HCO}_{3}{ }^{-}, 84.3 \%$ of the groundwaters were considered to be strongly influenced by the saline water, and $9.3 \%$ were slightly or moderately affected by industrial activities. Similar observations were made by Demirel (2004) to categorize the saline water intrusion by Chloride enrichment in Mersin-Kazanli coastal region of Turkey. A combined effect of seawater and urban wastewaters may also be a reason for the poor quality of groundwater, which 
Fig. 3 Geochemical classification of groundwater in the study area

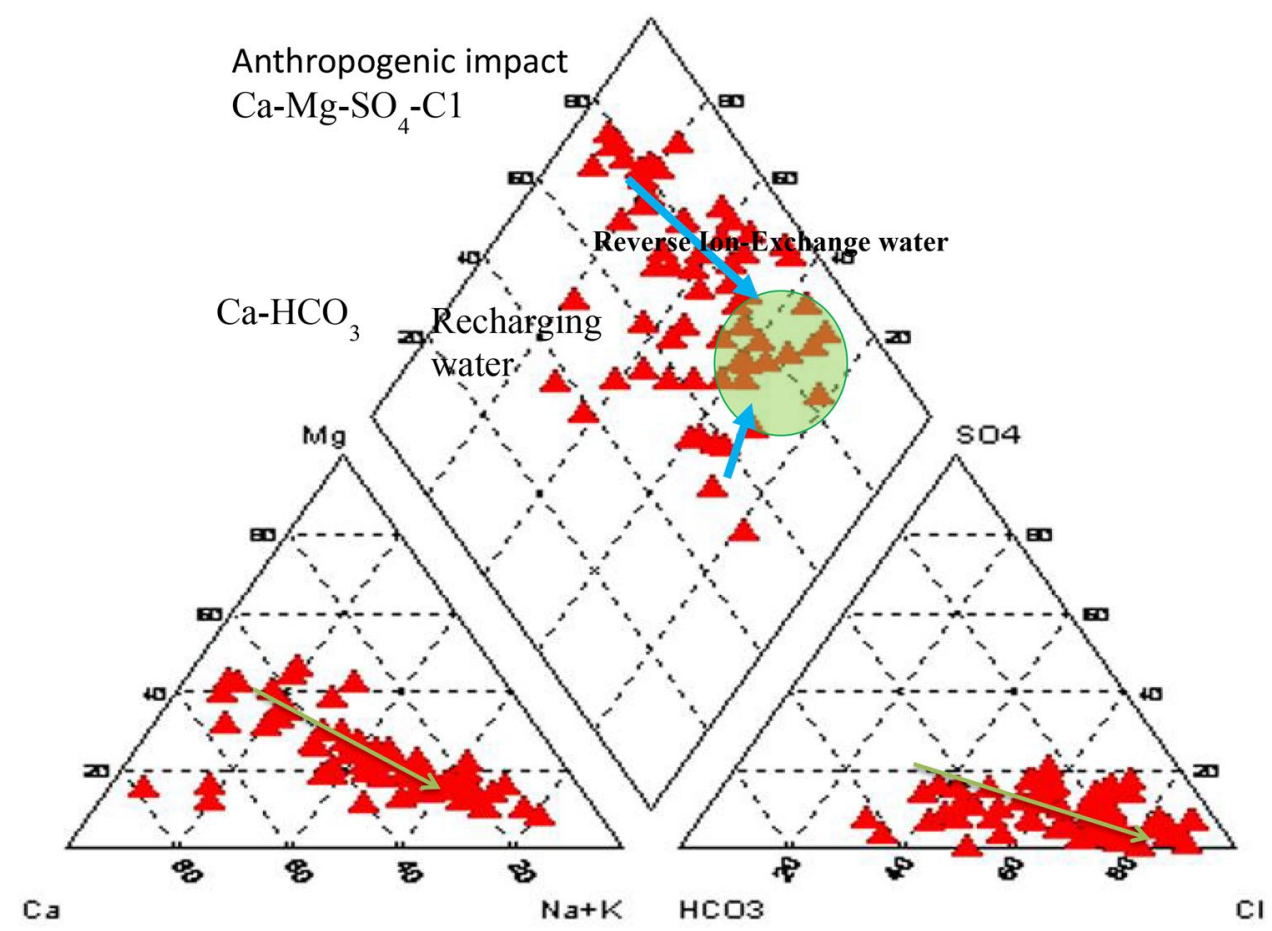

Fig. 4 Chadda's plot for groundwater samples to determine the chief chemical processes

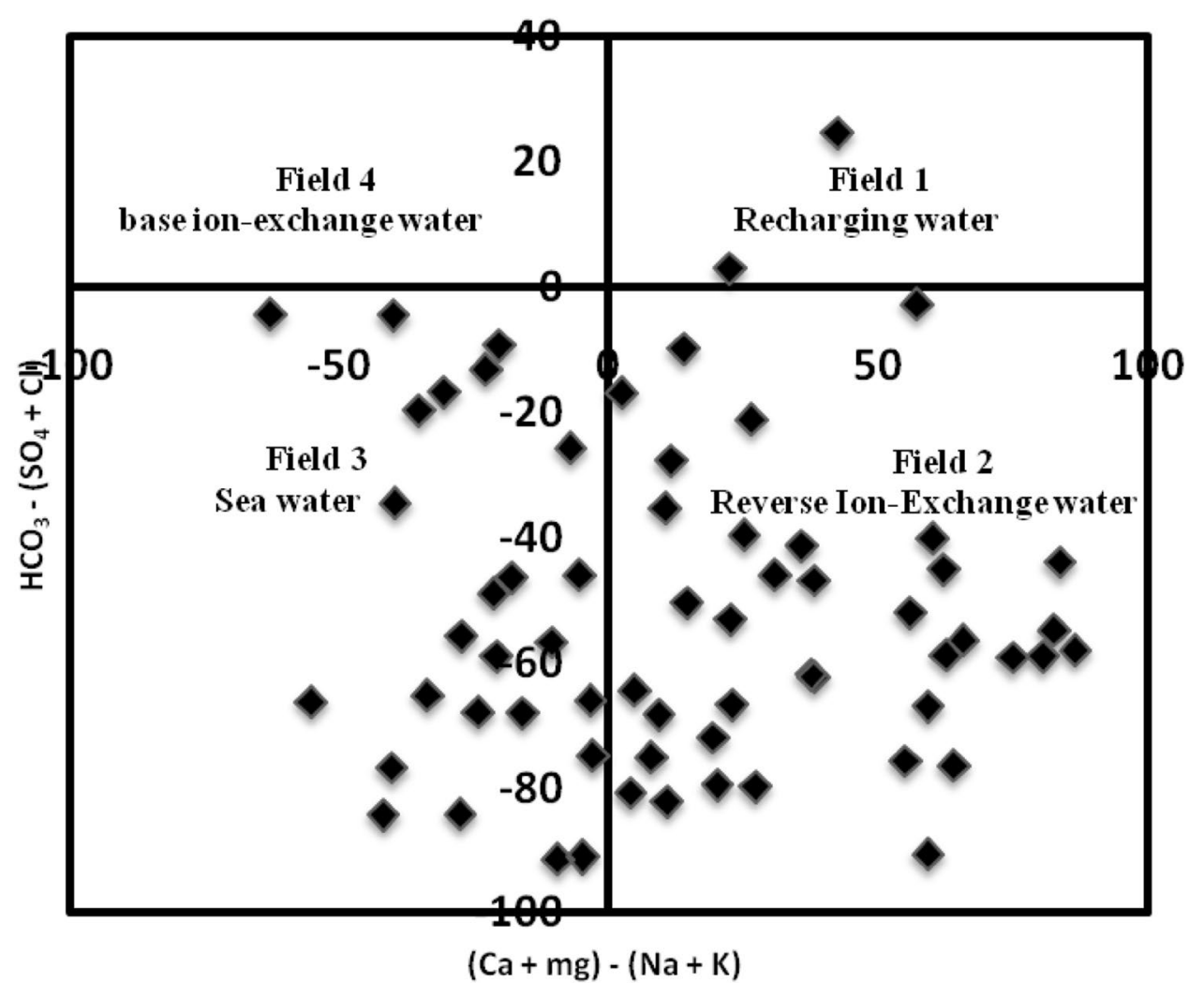

is influenced by topographic low close to the coastal area (Subba Rao et al. 2001). It was also interesting to note that $6.2 \%$ of the samples unaffected by salinization was located near Perumal Lake in the study area, which may be due to the dilution effect from the surface water recharged into the aquifer or lesser extraction of groundwater due to the increased usage of surface water. 
Fig. 5 Relationship between $\mathrm{Cl}^{-} / \mathrm{HCO}_{3}{ }^{-}$vs $\mathrm{Cl}^{-}$concentration in the study area

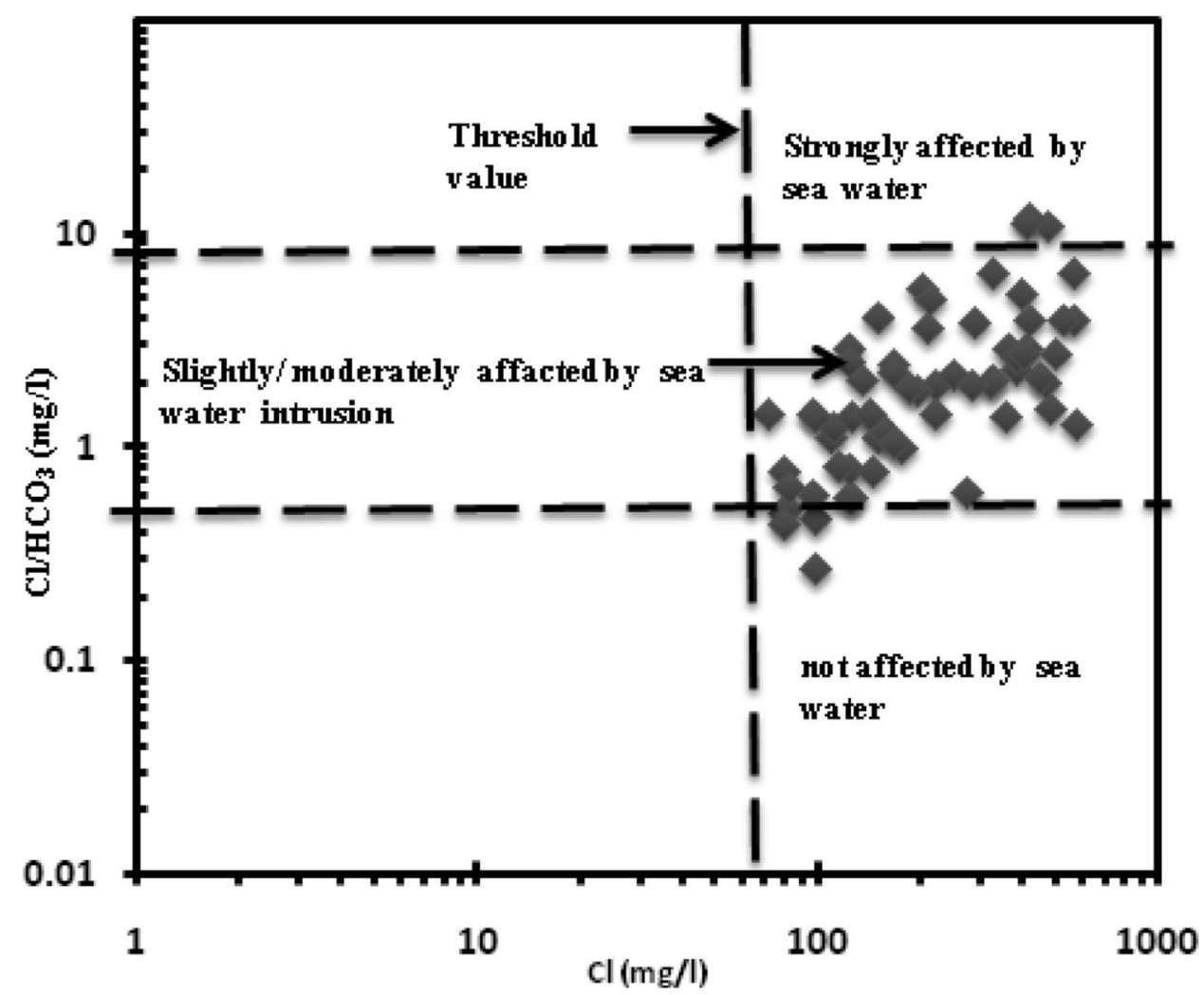

\section{$\log \mathrm{pCO}_{2}$}

Log $\mathrm{pCO}_{2}$ values for samples were calculated to determine the recharge processes (Prasanna et al. 2009; Raymahashay 1986). $\log \mathrm{pCO}_{2}$ value ranges from -5.34 to -0.05
(Fig. 6). The distribution of the ionic strength (IS) values in the samples varied from $<0.006$ to $>0.032$. There is a linear relationship between IS and $\log \mathrm{pCO}_{2}$. The increase of IS values reflects the long residence time of the saline water or due to the recharge of evaporated saline water (zone
Fig. 6 Relationship of $\log \mathrm{pCO}_{2}$ to ionic strength in the study area

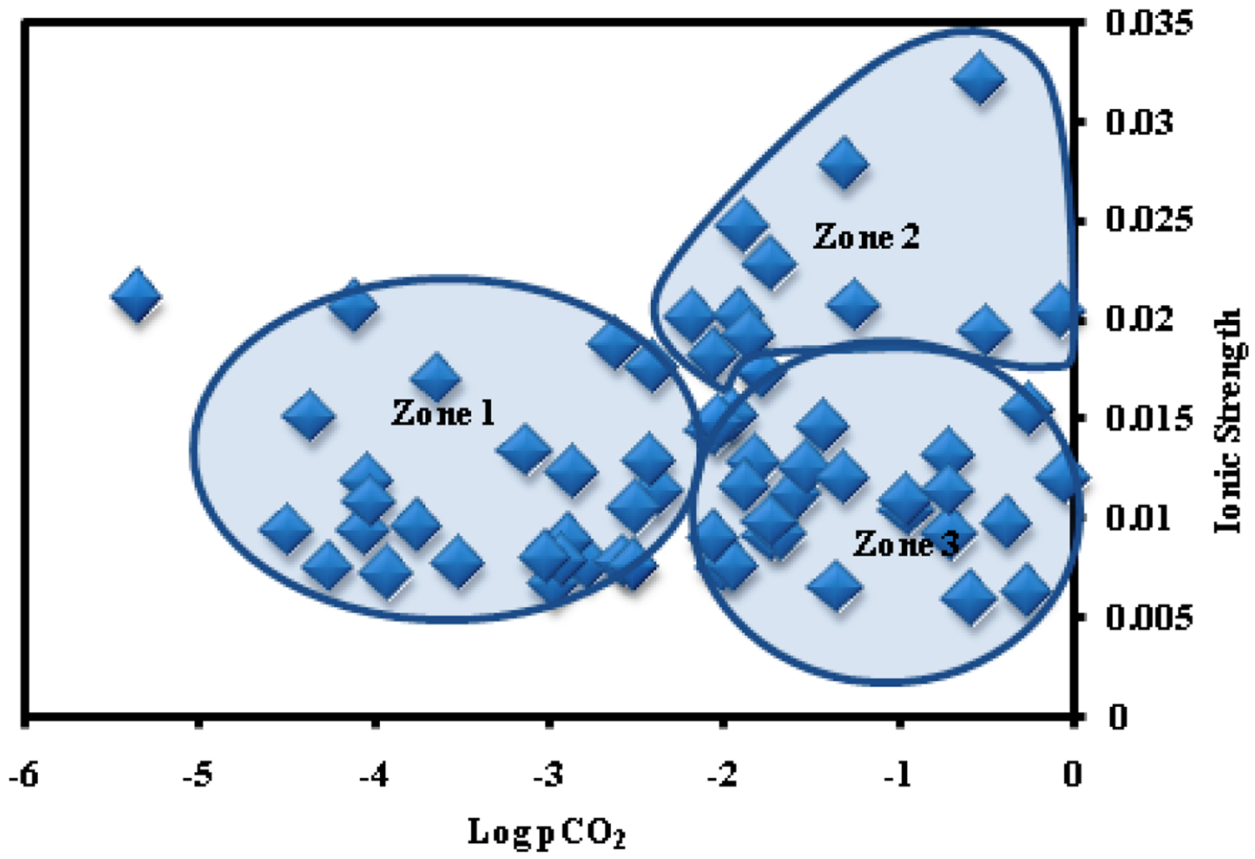


2). Low ionic strength and lower $\log \mathrm{pCO}_{2}$ values were noted in most of the samples (zone 1), which likely indicates inflow of fresh water to the aquifer (Prasanna et al. 2007). The lesser $\log \mathrm{pCO}_{2}$ values with higher ionic strength indicate closed system (Chidambaram et al. 2011). Hence it is understood that three basic environments are prevailing in the study area: frequent flushing region/open system, may be shallow groundwaters; groundwaters of the closed environment with long residence time and sea water intrusion regions. Samples are more prominently represented in zone 1 and zone 3.

Table 3 shows an extensive research on groundwater quality and its chemistry in the coastal aquifers at different parts of the world and compared with the present study area. Results from this study show that the mean value of $\mathrm{Ca}, \mathrm{Mg}, \mathrm{Na}, \mathrm{K}, \mathrm{HCO}_{3}$ and $\mathrm{SO}_{4}$ is comparatively lower than the other parts of the world except few locations. Interestingly, EC and TDS mean values are higher compared to other places except at Tuticorin, India. The mean value of $\mathrm{pH}$ is almost same as in other places. Overall, it indicates the ionic concentration in the coastal aquifers of present study is comparatively lower than in the other parts of the coastal aquifers worldwide.

\section{Environmental isotopes}

The local meteoric water line (LMWL) for Tamilnadu state exhibits an equation of $\delta \mathrm{D}=7.89 \delta^{18} \mathrm{O} \pm 10.38$ (Chidambaram et al. 2009), which is closer to the global meteoric water line (GMWL) derived by Rozanki et al. (1993). The slight variations are due to the different climatic influences which include air temperature, secondary evaporation, variation in precipitation, and moisture (Clark and Fritz 1997). The rain water isotope data for the region nearby the study area were taken from Chidambaram et al. (2009). It exhibits an LMWL (Fig. 7) of

$\delta \mathrm{D}=7.6 \delta^{18} \mathrm{O}+3.2$.

The results of $\delta \mathrm{D}$ and $\delta^{18} \mathrm{O}$ analyses show that isotopic compositions of groundwater range from -7.7 to $-2.1 \%$ o for $\delta^{18} \mathrm{O}$ and from -55.6 to $-18.5 \%$ for $\delta \mathrm{D}$. The comparison of the stable isotopes of the rain water with the groundwater samples show that most of the samples (Group A) fall in line with the LMWL indicating the recharge from the local rainfall recharge. There are few samples (Group B) indicative of evaporative enrichment/sea water intrusion. It is also observed that the heavier isotopes are more in five samples which may be due to the precipitation near the shore or that of saline water intrusion (Prasanna et al. 2009). The origin of salinization in ground water is generally distinguished by using $\delta \mathrm{D}-\delta^{18} \mathrm{O}$ relationship, because the stable isotope fractionation is mostly related to temperature

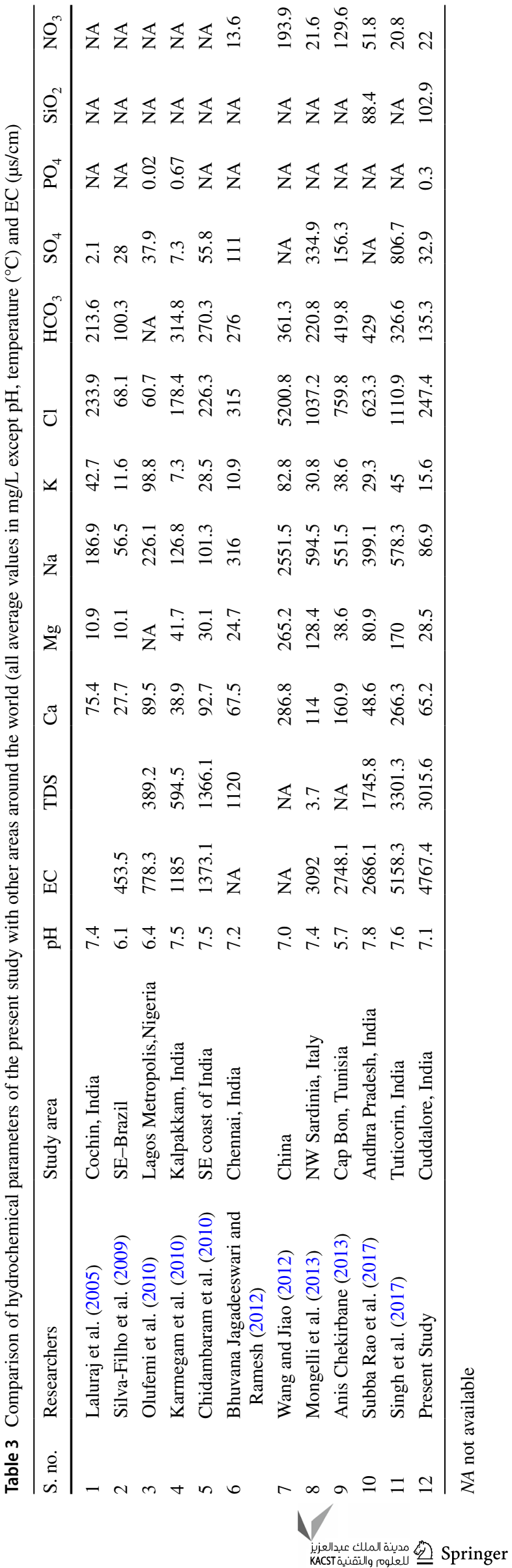


Fig. 7 Plot for $\delta^{18} \mathrm{O}$ versus $\delta \mathrm{D}$ of groundwater samples

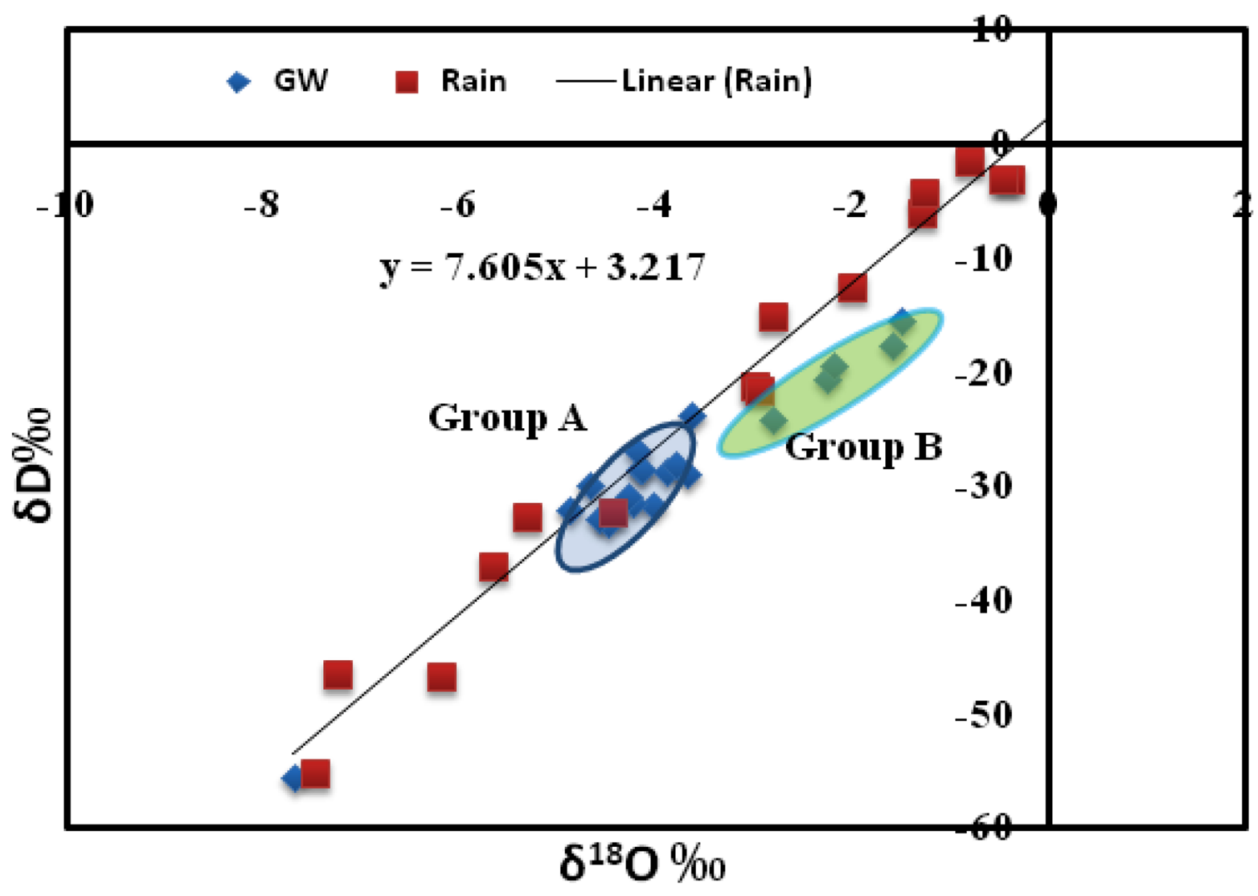

(Kendall and McDonnel 1998; Huddart et al. 1999). Group B samples also show that there is an end member of isotopic composition indicating sea water intrusion. It is evident that there is a clear mixing noted in between meteoritic samples and the sea water end member.

\section{Relationship between $\delta^{18} 0$ vs EC and Cl}

The relationship of the stable isotopes with the groundwater quality in this region was studied by plotting $\delta^{18} \mathrm{O}$, $\delta \mathrm{D}, \mathrm{EC}$, and $\mathrm{Cl}^{-}$. Figures 8 and 9 show the connections amongst $\delta^{18} \mathrm{O}$ and $\mathrm{EC}$, and $\mathrm{Cl}^{-}$, respectively. The comparison of $\delta D$ and EC shows that most of the samples (Zone I) fall in recharge region; the six samples (Zone II) fall in other sources of the region and five samples (Zone III) are indicative of seawater intrusion. So it indicates that during the mixing of fresh groundwater and highly mineralized brine, the water quality and $\delta^{18} \mathrm{O}$ value rise with the quantity of the mixing waters. In zone III, it is evident that $\delta^{18} \mathrm{O}$ increases with a linear logarithm relationship with $\mathrm{Cl}^{-}$and EC in the mixing process (Dutkiewicz et al. 2000).
Fig. 8 Plot for $\delta^{18} \mathrm{O}$ versus EC for groundwater samples




Fig. 9 Plot for $\delta^{18} \mathrm{O}$ versus $\mathrm{Cl}$ for groundwater samples

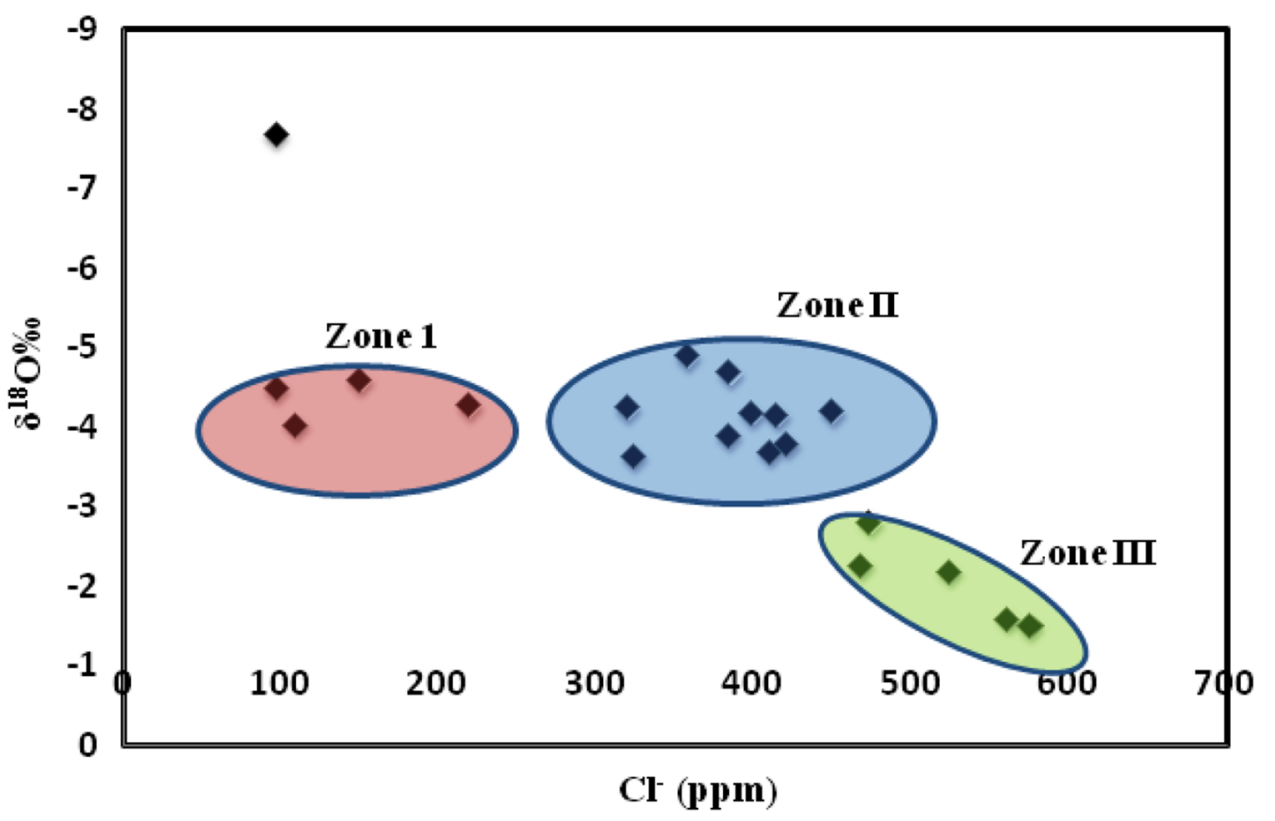

$\delta^{18} \mathrm{O}$ vs $\mathrm{Cl}$ diagram (Fig. 9) show similar trend to that of $\delta^{18} \mathrm{O}$ vs EC. Relationship between $\delta^{18} \mathrm{O}$ and $\mathrm{Cl}$ indicates the mixing trend with rainfall recharged fresh water and the sea water in Zone III samples and it is confirmed by the $\mathrm{Cl}-\delta^{18} \mathrm{O}$ relationship (Kim et al. 2003). In comparison with other groundwater samples, the sample numbers $1,7,18,30$, and 28 are enriched and noted to deviate significantly from the LMWL (Fig. 7), and also they have elevated $\mathrm{Cl}^{-}$contents (Fig. 9). These five samples which fall along the line have slope 4.01, which is lower than LMWL (7.6), and it is recognized by evaporation and/or mixing of groundwater with seawater.

\section{Correlation analyses}

$\mathrm{Cl}^{-}-\mathrm{Ca}^{2+}$ and $\mathrm{Mg}^{2+}-\mathrm{Ca}^{2+}$ ions are positively correlated $(>0.5)$, which indicates the salinization near the industrial area due to the enrichment of some salts $\left(\mathrm{CaCl}_{2}, \mathrm{MgCl}_{2}\right.$, and $\mathrm{Na}_{2} \mathrm{SO}_{4}$ ) including halite and gypsum. Then less significant correlation $(0.3-0.5)$ was noted between $\mathrm{Cl}^{-}-\mathrm{Na}^{+}$, $\mathrm{Mg}^{2+} ; \mathrm{HCO}_{3}{ }^{-}-\mathrm{Ca}^{2+}, \mathrm{Mg}^{2+} ; \mathrm{PO}_{4}{ }^{2-}-\mathrm{K}^{+}, \mathrm{SO}_{4}{ }^{2-}$. Generally, almost all ions have a positive correlation with $\mathrm{Cl}^{-}$, especially $\mathrm{Ca}^{2+}$ and $\mathrm{Mg}^{2+}$ (Table 4), revealing the derivation from similar source of salt waters (Kim et al. 2003). This correlation also signifies dissolution and leaching of secondary salts, with a significant correlation of $\mathrm{HCO}_{3}{ }^{-}$with $\mathrm{Ca}^{2+}, \mathrm{Mg}^{2+}, \mathrm{PO}_{4}{ }^{2-}, \mathrm{K}^{+}$, and $\mathrm{SO}_{4}{ }^{2-}$. Hence there may be interplay of the saline water intrusion and the leaching of the salts. $\mathrm{NO}_{3}{ }^{-}, \mathrm{PO}_{4}{ }^{2-}, \mathrm{SO}_{4}{ }^{2-}$, and $\mathrm{H}_{4} \mathrm{SiO}_{4}$ are poorly

Table 4 Correlation matrix for groundwater the chemical constitution present in groundwater of the study area

\begin{tabular}{|c|c|c|c|c|c|c|c|c|c|c|c|}
\hline & $\mathrm{Ca}^{2+}$ & $\mathrm{Mg}^{2}$ & $\mathrm{Na}^{+}$ & $\mathrm{K}^{+}$ & $\mathrm{Cl}^{-}$ & $\mathrm{HCO}_{3}^{-}$ & $\mathrm{NO}_{3}^{-}$ & $\mathrm{PO}_{4}^{-}$ & $\mathrm{SO}_{4}{ }^{2-}$ & $\mathrm{H}_{4} \mathrm{SiO}_{4}$ & $\mathrm{pH}$ \\
\hline $\mathrm{Ca}^{2+}$ & 1 & & & & & & & & & & \\
\hline $\mathrm{Mg}^{2+}$ & 0.749 & 1 & & & & & & & & & \\
\hline $\mathrm{Na}^{+}$ & -0.111 & 0.004 & 1 & & & & & & & & \\
\hline $\mathrm{K}^{+}$ & -0.056 & -0.007 & 0.166 & 1 & & & & & & & \\
\hline $\mathrm{Cl}^{-}$ & 0.519 & 0.495 & 0.438 & 0.057 & 1 & & & & & & \\
\hline $\mathrm{HCO}_{3}^{-}$ & 0.317 & 0.336 & 0.263 & -0.167 & 0.203 & 1 & & & & & \\
\hline $\mathrm{NO}_{3}^{-}$ & -0.072 & -0.137 & -0.171 & -0.026 & -0.299 & 0.145 & 1 & & & & \\
\hline $\mathrm{PO}_{4}^{-}$ & 0.013 & 0.082 & 0.12 & 0.422 & -0.004 & -0.147 & -0.202 & 1 & & & \\
\hline $\mathrm{SO}_{4}{ }^{2-}$ & 0.032 & -0.018 & -0.1 & 0.233 & -0.175 & -0.159 & -0.069 & 0.303 & 1 & & \\
\hline $\mathrm{H}_{4} \mathrm{SiO}_{4}$ & 0.078 & 0.008 & 0.115 & 0.077 & 0.255 & 0.1 & -0.034 & -0.096 & -0.049 & 1 & \\
\hline $\mathrm{pH}$ & -0.14 & -0.013 & 0.042 & 0.05 & -0.101 & 0.055 & 0.367 & 0.05 & -0.076 & -0.395 & 1 \\
\hline
\end{tabular}


correlated with other ions, indicating the individual complex processes (Briz-kishore and Murali 1992).

\section{Factor analysis}

Five factors were extracted with $75.29 \%$ of total data variability (TDV). Factor 1 represents $\mathrm{Na}^{+}, \mathrm{Ca}^{2+}, \mathrm{Mg}^{2+}$, and $\mathrm{Cl}^{-}$(Table 5), which indicates the prevalence of reverse ion exchange induced by seawater intrusion (Kim et al. 2003). Factor 2 was characterized by $\mathrm{K}^{+}, \mathrm{PO}_{4}{ }^{-}$, and $\mathrm{SO}_{4}{ }^{2-}$ showing that anthropogenic signature comes from fertilizers. Factor 3 represented by $\mathrm{Na}^{+}$and $\mathrm{Cl}^{-}$indicates the saline water intrusion to the aquifer increases the concentration of these ions. Factor 4 characterized by $\mathrm{H}_{4} \mathrm{SiO}_{4}$ indicate silicate weathering. The study area is principally consisting of alumino silicates, which undertake weathering and discharge silica into the solution. Poor representation of $\mathrm{Ca}^{2+}$ and $\mathrm{HCO}_{3}{ }^{-}$in this factor is due to the enrichment of silica by the precipitation processes of carbonate minerals from the system. Factor 5 is heavily loaded by $\mathrm{NO}_{3}{ }^{-}$indicating the impact of nitrate fertilizer. Nitrate is also probably the most wide-spread contaminant in groundwater which originates from both urban as well as agricultural activities (Nkotagu 1996; Stigter et al. 1998; Zilberbrand et al. 2001; Perez et al. 2003; Min et al. 2003). Hence, it is inferred that the reverse ion exchange, anthropogenic influence, and the sea water intrusion play a major role in determining the groundwater chemistry of the region.

Table 5 Factor analyses for the chemical composition of groundwater in the study area

\begin{tabular}{lrrrrr}
\hline & Factor 1 & Factor 2 & Factor 3 & Factor 4 & Factor 5 \\
\hline $\mathrm{Ca}^{2+}$ & 0.93 & 0.00 & -0.10 & 0.09 & -0.01 \\
$\mathrm{Mg}^{2+}$ & 0.91 & 0.04 & 0.03 & -0.07 & -0.04 \\
$\mathrm{Na}^{+}$ & -0.05 & 0.11 & 0.90 & 0.03 & -0.05 \\
$\mathrm{~K}^{+}$ & -0.07 & 0.79 & 0.21 & 0.09 & 0.10 \\
$\mathrm{Cl}^{-}$ & 0.59 & -0.03 & 0.57 & 0.17 & -0.24 \\
$\mathrm{HCO}_{3}{ }^{-}$ & 0.45 & -0.23 & 0.35 & 0.07 & 0.45 \\
$\mathrm{NO}_{3}{ }^{-}$ & -0.11 & -0.07 & -0.18 & -0.07 & 0.89 \\
$\mathrm{PO}_{4}{ }^{2-}$ & 0.05 & 0.76 & 0.09 & -0.19 & -0.21 \\
$\mathrm{SO}_{4}{ }^{2-}$ & 0.03 & 0.64 & -0.38 & 0.07 & -0.05 \\
$\mathrm{H}_{4} \mathrm{SiO}_{4}$ & 0.03 & 0.02 & 0.18 & 0.89 & 0.12 \\
$\mathrm{pH}^{\text {Eigen values }}$ & -0.06 & 0.06 & 0.16 & -0.72 & 0.47 \\
$\%$ of variance & 2.27 & 1.70 & 1.56 & 1.41 & 1.34 \\
Cumulative \% & 20.67 & 15.45 & 14.16 & 12.85 & 12.17 \\
\hline
\end{tabular}

\section{Conclusions}

Groundwater is an important source of drinking water for many people around the world. In the present study, the relative concentrations of cations and anions occur in the order of $\mathrm{Na}^{+}>\mathrm{Ca}^{2+}>\mathrm{Mg}^{2+}>\mathrm{K}^{+}$and $\mathrm{Cl}^{-}>\mathrm{HCO}_{3}^{-}>\mathrm{H}_{4} \mathrm{SiO}_{4}>\mathrm{SO}_{4}{ }^{2-}>\mathrm{NO}_{3}{ }^{-}>\mathrm{PO}_{4}{ }^{-}$. The dominant hydrochemical facies of groundwater in the study area is $\mathrm{Ca}-\mathrm{Mg}-\mathrm{SO}_{4}-\mathrm{Cl}, \mathrm{Ca}-\mathrm{HCO}_{3}$, and $\mathrm{Na}-\mathrm{Cl}$ types indicating the geochemical variation along the groundwater flow path. The variation of $\log \mathrm{pCO}_{2}$ and ionic strength reveals three different types of water: frequent flushing, sea water ingression, and long residence time of water in the aquifer system. $\delta \mathrm{D}$ and $\mathrm{EC}$ of the groundwater samples show that most of the samples fall in recharge region; six samples fall in other sources of the region and five samples are indicative for seawater intrusion. The $\mathrm{Cl}^{-} /\left(\mathrm{Cl}^{-}+\mathrm{HCO}_{3}^{-}\right)$ratios and statistical analysis reveal the fact that sea water ingression, silicate weathering, and ion exchange process govern the geochemistry of coastal groundwater in the study area.

Acknowledgements The authors are grateful to the anonymous referees for their constructive comments and suggestions, which led to significant improvement to the manuscript. Authors also thank Ms. Banajarani Panda for proof reading the manuscript.

Open Access This article is distributed under the terms of the Creative Commons Attribution 4.0 International License (http://creativeco mmons.org/licenses/by/4.0/), which permits unrestricted use, distribution, and reproduction in any medium, provided you give appropriate credit to the original author(s) and the source, provide a link to the Creative Commons license, and indicate if changes were made.

\section{References}

Ahmad J, Ahmed A-F, Natarajan R, Saif A-Y (2008) Assessment of groundwater vulnerability in the coastal region of Oman using DRASTIC index method in GIS environment. Environ Monit Assess 147:125-138

American Public Health Association (APHA) (2005) Standard method for examination of water and wastewater, 21st edn. APHA, AWWA, WPCF, Washington

Anis C, Maki T, Atsushi K, Hiroko I, Jamila T, Abdallah B (2013) Hydrogeochemistry and groundwater salinization in an ephemeral coastal flood plain: Cap Bon. Tunisia, Hydrol Sci J 58(5):1097-1110

Appelo C, Postma D (1996) Geochemistry, groundwater and pollution. Balkema, Rotterdam

Arogyasami RNP (1967) Report on the examination of the tertiary and Cretaceous areas in South Arcot and Tiruchirapally districts. G.S.I report, Madras

Barut IF (2015) Origin of groundwater salinity and hydrogeochemical processes in a confined coastal karst aquifer: a cause of the Mandalia Bay (southeastern Aegean coasts). Int J Environ Geoinform 2(1):25-46 
Bhuvana Jagadeeswari P, Ramesh K (2012) Water quality index for assessment of water quality in South Chennai coastal aquifer, Tamilnadu, India. Int J ChemTech Res 4:1582-1588

Boukari M, Gaye CB, Faye A, Faye S (1996) The impact of urban development on coastal aquifers near Cotonou, Benin. J Afr Earth Sci 22(4):403-408

Briz-kishore BH, Murali G (1992) Factor analysis for revealing hydrogeochemical characteristics of a watershed. Environ Geol 19:3-9

Carol E, Kruse E, Mas-Pla J (2009) Hydrochemical and isotopic evidence of groundwater salinization processes on the coastal plain of Samborombon Bay, Argentina. J Hydrol 365:335-345

Centre for Groundwater Board (CGWB) (1997) Groundwater resources and development prospects in South Arcot-Vallalar District, Tamilnadu. South Eastern Coastal Region, Chennai

CGWB (2009) Report on the working group on the estimation of groundwater resources and irrigation potential of Periyar district, Tamilnadu. CGWB report

Chekirbane A, Tsujimura M, Kawachi A, Isoda H, Tarhouni J, Benalaya A (2013) Hydrogeochemistry and groundwater salinization in an ephemeral coastal flood plain: Cap Bon, Tunisia. Hydrol Sci J 58(5):1097-1110

Chidambaram S, Prasanna MV, Ramanathan AL, Vasu K, Hameed S, Warrier UK, Srinivasamoorthy K, Manivannan R, Tirumalesh K, Anandhan P, Johnsonbabu G (2009) A study on the factors affecting the stable isotopic composition in precipitation of Tamil Nadu, India. Hydrol Process 23:1792-1800

Chidambaram S, Ramanathan AL, Prasanna MV, Karmegam U, Dheivanayagi V, Ramesh R (2010) Study on the hydrogeochemical characteristics in groundwater, post- and pre-tsunami scenario, from Portnova to Pumpuhar, southeast coast of India. Environ Monit Assess 169:553-568

Chidambaram S, Karmegam U, Prasanna MV, Sasidhar P, Vasanthavigar M (2011) A study on hydrochemical elucidation of coastal groundwater in and around Kalpakkam region, Southern India. Environ Earth Sci 64:1419-1431

Clark I, Fritz P (1997) Environmantal isotopes in hydrology. Lewis publishers, Boca Raton, p 328

Demirel Z (2004) The history and evaluation of saltwater intrusion into a coastal aquifer in Mersin, Turkey. J Environ Manag 70(3):275-282

Domenico PA, Schwartz FW (1990) Physical and chemical hydrogeology. Wiley, New York, pp 410-420

Dutkiewicz A, Herczeg AL, Dighton JC (2000) Past changes to isotopic and solute balances in a continental playa: clues from stable isotopes of lacustrine carbonates. Chem Geol 165:309-329

Egun NK (2010) Effect of channelling wastewater into water bodies: a case study of the Orogodo River in Agbor, Delta State. J Hum Ecol 31(1):47-52

Faye SC, Faye S, Wohnlich S, Gaye CB (2004) An assessment of the risk associated with urban development in the Thiaroye area (Senegal). Environ Geol 45:312-322

Fengshan M, Wei A, Qinghai D, Haijun Z (2014) Hydrochemical characteristics and the suitability of groundwater in the coastal region of Tangshan, China. J Earth Sci 25(6):1067-1075

Foppen JWA (2002) Impact of high-strength wastewater infiltration on groundwater quality and drinking water supply: the case of Sana'a, Yemen. J Hydrol 263:198-216

Giménez-Forcada E (2010) Dynamic of seawater interface using hydrochemical facies evolution diagram (HFE-D). Groundwater 48(2):212-216

Huddart D, Bennett MR, Glasser NF (1999) Morphology and sedimentology of a high-arctic esker system, Vesbreen, Svalbard. Boreas 28:253-273

Jeen SK, Kim JM, Ko KS, Yum B, Chang HW (2001) Hydrogeochemical characteristics of groundwater in a Midwestern coastal aquifer system, Korea. Geosci J 5:39-348
Jeevanandam M, Kannan R, Srinivasalu S, Rammohan V (2006) Hydrogeochemistry and groundwater quality assessment of lower part of the Ponnaiyar River Basin, Cuddalore district. Environ Monit Assess 132(1):263-274

Karmegam U, Chidambaram S, Sasidhar P, Manivannan R, Manikandan S, Anandhan P (2010) Geochemical characterization of groundwaters of shallow coastal aquifer in and around Kalpakkam, South India. Res J Environ Earth Sci 2(4):170-177

Karmegam U, Chidambaram S, Prasanna MV, Sasidhar P (2011) A study on the mixing proportion in the groundwater samples by Piper Diagram and Phreeqc Model". Chin J Geochem 30:490-495

Kelley WP (1940) Permissible composition and concentration of irrigation waters. Proc ASCE 66:607

Kendall C, McDonnel JJ (eds) (1998) Isotope tracers in catchment hydrology. Elsevier Science B.V, Amsterdam, p 839

Kim Y, Lee K, Koh D, Lee D, Lee S, Park W, Koh G, Woo N (2003) Hydrogeochemical and isotopic evidence of groundwater salinization in a coastal aquifer: a case study in Jeju volcanic island, Korea. J Hydrol 270:282-294

Laluraj CM, Gopinath G, Dineshkumar PK (2005) Groundwater chemistry of shallow aquifers in the coastal zones of Cochin, India. Appl Ecol Environ Res 3(1):133-139

Lambrakis NJ (1998) The impact of human activities in the Malia coastal area (Crete) on groundwater quality. Environ Geol 36:87-98

Martínez DE, Bocanegra EM (2002) Hydrogeochemistry and cation-exchange processes in the coastal aquifer of Mar Del Plata, Argentina. Hydrogeol J 10(3):393-408

Mercado A (1985) The use of hydrogeochemical patterns in carbonate sand and sandstone aquifers to identify intrusion and flushing of saline waters. Groundwater 23(5):635-645

Min JH, Yun ST, Kim K, Kim HS, Kim DJ (2003) Geologic controls on the chemical behavior of nitrate in riverside alluvial aquifers, Korea. Hydrol Proc 17:1197-1211

Mohapatra PK, Vijay R, Pujari PR, Sundaray SK, Mohanty BP (2011) Determination of processes affecting groundwater quality in the coastal aquifer beneath Puri city, India: a multivariate statistical approach. Water Sci Technol 64(4):809-817

Mongelli G, Monni S, Oggiano G, Paternoster M, Sinisi R (2013) Tracing groundwater salinization processes in coastal aquifers: a hydrogeochemical and isotopic approach in the $\mathrm{Na}-\mathrm{Cl}$ brackish waters of northwestern Sardinia, Italy. Hydrol Earth Syst Sci 17:2917-2928

Nkotagu H (1996) Origins of high nitrate in groundwater in Tanzania. J African Earth Sci 21:471-478

Nwankwoala HO, Judom G (2011) Hydrogeochemical evaluation of groundwater in parts of Eastern Niger Delta, Nigeria. J Acad Appl Stud 1(2):33-58

Olufemi AG, Utieyin OO, Adebayo OM (2010) Assessment of groundwater quality and saline intrusions in coastal aquifers of Lagos Metropolis, Nigeria. J Water Resour Protect 2:849-853

Ozler HM (2003) Hydrochemistry and salt-water intrusion in the Van aquifer, East Turkey. Environ Geol 43:759-775

Papazotos P, Koumantakis I, Vasileiou E (2016) Seawater intrusion and nitrate pollution in coastal aquifer of marathon basin. Bull Geol Soc Greece 50:927-937

Perez JMS, Antiguedad I, Arrate I, Linares CG, Morelld I (2003) The influence of nitrate leaching through unsaturated soil on groundwater pollution in an agricultural area of the Basque country: a case study. Sci Total Environ 317:173-187

Piper AM (1944) A graphical interpretation of water analysis. Trans Am Geophys Union 25:914-928

Prasanna MV, Chidambaram S, Srinivasamoorthy K, JohnPeter A, Anandhan P (2007) Hydrogeochemical characterization of




groundwater in Gadilam River Basin, through statistical analysis. Int Q J Environ Soc Sci 2(1):21-26

Prasanna MV, Chidambaram S, Shahul Hameed A, Srinivasamoorthy K (2009) Study of evaluation of groundwater in Gadilam basin using hydrogeochemical and isotope data. Environ Monit Assess 168:63-90

Pulido-Leboeuf P (2004) Seawater intrusion and associated processes in a small coastal complex aquifer (Castell de Ferro, Spain). Appl Geochem 19:1517-1527

Raymahashay BC (1986) Geochemistry of bicarbonate in river water. J Geol Soc India 27:114-118

Revelle R (1941) Criteria for recognition of sea water in groundwaters. Trans Am Geophys Union 22:593-597

Richter BC, Kreitler CW (1993) Geochemical techniques for identifying sources of ground-water salinization. CRC, Boca Raton, p 258

Rozanki K, Araguas-araguas L, Gonfiantini R (1993) Isotopic patterns in modern global precipitation. In: Swart PK, Lobmann KC, Mckenzie J, Savin S (eds) Climate change in continental isotopic records: American Geophysical Union Geophysical Monograph, vol 78, pp 1-36

Sanchez Martos F, Pulido Bosch A, Calaforra JM (1999) Hydrogeochemical processes in an arid region of Europe (Almeria, SE Spain). Appl Geochem 14:735-745

Sanford WE, Pope JP (2010) Current challenges using models to forecast seawater intrusion: lessons from the Eastern Shore of Virginia, USA. Hydrogeol J 18(1):73-93

Sankaran S, Saheb Rao S, Krishnakumar K (2009) Micro level groundwater quality/groundwater movement in Cuddalore SIPCOT, Tamilnadu, p 67. Technical Report No. NGRI-2009-GW-689

Silva-Filho EV, Sobral Barcellos RG, Emblanch C, Blavoux B, Sella SM, Daniel M, Simler R, Wasserman JC (2009) Groundwater chemical characterization of a Rio De Janerio coastal aquifer, SE-Brazil. J S Am Earth Sc 27:100-108

Singaraja C, Chidambaram S, Anandhan P, Prasann MV, Thivya C, Thilagavathi R (2012) A study on the status of fluoride ion in groundwater of coastal hard rock aquifers of south India. Arab J Geosci 6(11):4167-4177

Singaraja C, Chidambaram S, Anandhan P, Prasanna MV, Thivya C, Thilagavathi R (2015) A study on the status of saltwater intrusion in the coastal hard rock aquifer of South India. Environ Dev Sustain 17:443-475

Singh S, Mondal NC, Singh VS (2017) Groundwater quality in and around Tuticorin town, Southeast coast of India. J Ind Geophys Union 21:34-43

Stigter TY, Ooijen SPJV, Post VEA, Appello CAJ, Dill AMMC (1998) A hydrogeological and hydrochemical explanation of the groundwater composition under irrigated land in a Mediterranean environment, Algarve, Portugal. J Hydrol 208:262-279
Subba Rao N (2006) Seasonal variation of groundwater quality in a part of Guntur District, Andhra Pradesh, India. Environ Geol 49:413-429

Subba Rao N, Prakasa Rao J, John Devadas D, Srinivasa Rao K, Krishna C (2001) Multivariate analysis for identifying the governing factors of groundwater quality. J Environ Hydrol 9(16):1-9

Subba Rao N, Surya Rao P, Venktram Reddy G, Nagamani M, Vidyasagar G, Satyanarayana NLVV (2012) Chemical characteristics of groundwater and assessment of groundwater quality in Varaha River Basin, Visakhapatnam District, Andhra Pradesh, India. Environ Monit Assess 184:5189-5214

Subba Rao N, Vidyasagar G, Surya Rao P, Bhanumurthy P (2017) Chemistry and quality of groundwater in a coastal region of Andhra Pradesh, India. Appl Water Sci 7:285-294

Subramaniam V (1969) Geology and ground water aspects of the Neyveli lignite field, South Arcot District, Madras State. Mem Geol Sur of India, p 94

Sundaram R (1979) Geology of upper Cretaceous and Tertiary formations of parts of Ulundurpettai, Viruddachalam and Panruti taluks of South Arcot Distrcts, Tamilnadu. Int J Ecol Environ Sci Special issue 31(3):299-306

Surinaidu L (2016) Role of hydrogeochemical process in increasing groundwater salinity in the central Godavari delta. Hydrol J 47(2):373-389

Thilagavathi R, Chidambaram S, Prasanna MV, Thivya C, Singaraja C (2012) A study on groundwater geochemistry and water quality in layered aquifers system of Pondicherry region, southeast India. Appl Water Sci 2:253-269

Todd DK (1959) Groundwater hydrology. Wiley, New York

Todd DK (1980) Groundwater hydrology. Wiley, New York

Varma VK, Malhotra S, Yoo ES, Jiloha RC, Finnerty MT, Susser E (1996) Course and outcome of acute non-organic psychotic states in India. Psychiatr Q 67:195-207

Wang Y, Jiao JJ (2012) Origin of groundwater salinity and hydrogeochemical processes in the confined Quaternary aquifer of the Pearl River delta, China. J Hydrol 438-439:112-124

Zilberbrand M, Rosenthal E, Shachnai E (2001) Impact of urbanization on hydrochemical evolution of groundwater and on unsaturatedzone gas composition in the coastal city of Tel Aviv, Israel. J Contam Hydrol 50(3-4):175-208

Publisher's Note Springer Nature remains neutral with regard to jurisdictional claims in published maps and institutional affiliations. 